Журнал«Герстективита інновації наукиљ

(Серія«Гедагогіка», Серія«ГЕихологія», Серія«Медицина»

№4(4) 2021

УДК 796.077.5:378(4-17)

https://doi.org/10.52058/2786-4952 -2021-4(4)-214-222

Криштанович Світлана Володимирівна доктор педагогічних наук, доцент, професор кафедри педагогіки та психології, Львівський державний університет фізичної культури імені Івана Боберського, вул. Тадеуша Костюшка, 11, м. Львів, 79000, тел.: (0322) 55-32-01, e-mail: skrischtanovich@ gmail.com, https://orcid.org/0000-0002-2147-9028

Самсонюк Людмила Свгенівна викладач кафедри педагогіки та психології, Львівський державний університет фізичної культури імені Івана Боберського, вул. Тадеуша Костюшка, 11, м. Львів, 79000, тел.: (0322) 55-32-01, e-mail: samsonyuku1@ gmail.com, https://orcid.org/0000-0002-7809-4129

\title{
ІННОВАЦІЙНО-ОРІЕНТОВАНА СИСТЕМА ОСВІТИ МАЙБУТНІХ МАГІСТРІВ У СФЕРІ ФІЗИЧНОЇ КУЛЬТУРИ І СПОРТУ В СКАНДИНАВСЬКИХ КРАЇНАХ
}

Анотація. Аналіз проведеного дослідження підтверджує високий рівень вищої освіти в Скандинавських країнах. Активна участь держави у системі освіти та ії інноваційно-орієнтована економіка дає змогу безкоштовно навчатися не тільки своїм мешканцям, а й навіть громадянам інших країн. Вища освіта у Скандинавських країнах ділиться на три рівні, що є зрозумілим при виборі своєї майбутньої діяльності для абітурієнтів, зокрема: університети, які зосереджені на теоретичних дисциплінах; університетські коледжі, які пропонують широкий спектр освітніх пропозицій; приватні школи, які спеціалізуються на затребуваних спеціальностях. Програма магістра в Університетському коледжі Молде (Норвегія) в галузі спортивного менеджменту призначена для підготовки магістрів до роботи на керівних посадах у сфері спорту та пов'язаних зі спортом секторах формує розуміння та знання про спорт, як це практикується в європейському просторі, ознайомлює магістрантів 3 юридичними, етичними, економічними, організаційними, історичними, політичними та психологічними науками, які необхідні для задоволення потреб спортивного сектора. Магістерська програма спортивних наук в Університет Мальме (Швеція) - це дворічна магістерська програма (Основна галузь: Спортивні науки), яка вивчає питання у сфері спорту та спортивної науки. Вона спрямована на забезпечення місцевих, регіональних, національних та міжнародних запитів у галузі спорту, спортивної науки та сталого суспільства. Освіта тісно пов'язана з науководослідним середовищем спортивної науки в Університеті Мальме, який має якісне дослідницьке середовище та визначну роль у наукових суперечностях 3 
питань спорту. Формування професійної компетентності фахівців у сфері спорту Скандинавських країн відбувається на високому професійному рівні. Для оптимального способу отримання знань використовують та шукають нові інноваційні методи навчання, що сприяє магістрам у кар'єрному зростанні та можливості отримувати роботу в Свропі та США.

Ключові слова: інновації, система освіти, магістри, фізична культура, спорт, спортивний менеджмент, професійна компетеність.

Kryshtanovych Svitlana Volodymyrivna Doctor of Pedagogical Sciences, Associate Professor, Professor of the Department of Pedagogy and Psychology, Lviv State University of Physical Culture named after Ivan Boberskyj, Tadeusz Kosciuszko St., 11, Lviv, 79000, tel.: (0322) 55-32-01, e-mail: skrischtanovich@gmail.com, https://orcid.org/0000-0002-2147-9028

Samsoniuk Liudmyla Yevhenivna Teacher at the Department of Pedagogy and Psychology, of Lviv State University of Physical Culture named after Ivan Boberskyj, 79000, Lviv, Tadeusz Kosciuszko St., 11, tel..: (0322) 55-32-01 e-mail: samsonyuku1@gmail.com, https://orcid.org/0000-0002-7809-4129

\section{INNOVATION-ORIENTED SYSTEM OF EDUCATION OF FUTURE MASTERS IN THE FIELD OF PHYSICAL CULTURE AND SPORTS IN THE SCANDINAVIAN COUNTRIES}

Abstract. The analysis of the study confirms the high level of higher education in the Scandinavian countries. The active participation of the state in the education system and its innovation-oriented economy allows free learning not only for its residents, but also for citizens of other countries. Higher education in the Scandinavian countries is divided into three levels, which is understandable when choosing their future activities for applicants: universities that focus on theoretical disciplines; university colleges that offer a wide range of educational offers; private schools that specialize in popular specialties. The Master's program at the University College Molde (Norway) in the field of sports management is designed to prepare masters to work in leadership positions in sports and sports-related sectors, forms an understanding and knowledge of sports as practiced in Europe, introduces undergraduates to legal, ethical, economic, organizational, historical, political and psychological sciences, which are necessary to meet the needs of the sports sector. The Master's program in Sports Science at the University of Malmö (Sweden) is a two-year master's program (Main field: Sports Sciences) that studies issues in the field of sports and sports science. It aims to meet local, regional, national and international demands in the field of sports, sports science and sustainable society. Education is closely linked to the research environment of sports science at the University of Malmö, which has a high-quality research environment and a prominent role in the scientific controversy 
over sports. The formation of professional competence of specialists in the field of sports in the Scandinavian countries is at a high professional level. Innovative teaching methods are used and sought for the best way to acquire knowledge, which promotes masters in career growth and job opportunities in Europe and USA.

Keywords: innovations, education system, masters, physical culture, sports, sports management, professional competence.

Постановка проблеми. Рівень освіти в цілому в країнах Скандинавії - один із найвищих у світі, держави виділяють 3 бюджету на розвиток цієї галузі значно більше (приблизно 7,7 \%), ніж у середньому по Європі (4,9\%). Тому вища освіта $\epsilon$ на належному рівні. Але стосовно певної «північної відокремленості» місцеві університети менш популярні, ніж в англомовних країнах.

Аналіз останніх досліджень і публікацій. Як стверджує В. Скрипник, під час навчання у закладах вищої освіти Скандинавських країн $є$ можливість набути практичного досвіду в місцевих та іноземних компаніях. 3 огляду на факт, що економіка країн інноваційно-орієнтована, вартість такого досвіду важко переоцінити. Активна участь держави у системі освіти дає змогу безкоштовно навчатися те тільки своїм мешканцям, а й навіть громадянам інших країн [1].

Є. Головчанська вказує, що вища освіта в Норвегії поділяється на три рівні:

- університети, які зосереджені на теоретичних дисциплінах (мистецтвознавство, гуманітарні науки, природничі науки). Ступінь бакалавра становить 3 роки навчання, магістра становить 2-3 роки та докторський ступінь - 3 роки. Університети також проводять низку професійних досліджень, зокрема у сферах права, медицини, стоматології, фармації та психології (це виконують певні кафедри, які причетні до університетських установ);

- університетські коледжі (høyskole), які пропонують широкий спектр освітніх пропозицій, зокрема університетські ступені бакалавра, магістра та докторантури, інженерні ступені та професії вчителя, медсестри. Система оцінок така ж, як і для університетів;

приватні школи, які спеціалізуються на затребуваних спеціальностях, але які обмежені у державних школах, зокрема управління бізнесом, маркетинг або образотворче мистецтво [2].

Мета статті - дослідити та проаналізувати систему освіти в Скандинавських країнах щодо формування професійної компетентності майбутніх магістрів фізичної культури і спорту.

Виклад основного матеріалу. Університетський коледж Молде (Molde University College) в м. Молде Норвегії - це спеціалізований університет логістики, який пропонує програми з логістики, економіки та менеджменту, спорту, соціальних наук, наук про здоров'я та соціальних служб. Програми бакалавра проводять норвезькою мовою та не викладають міжнародним абітурієнтам. На рівні магістра пропонують такі міжнародні програми англійською мовою: магістр у галузі нафтової логістики, магістр у галузі 
логістики та магістра в галузі спортивного менеджменту [3].

Програма магістра в галузі спортивного менеджменту (Master of Science in Sport Management) призначена для підготовки магістрів до роботи на керівних посадах у сфері спорту та пов'язаних зі спортом секторах. Вона формує розуміння та знання про спорт, як це практикується в європейському просторі, ознайомлює магістрантів 3 юридичними, етичними, економічними, організаційними, історичними, політичними та психологічними науками, які необхідні для задоволення потреб спортивного сектора [3].

Університетський коледж Молде (Molde University College) співпрацює 3 футбольною асоціацією Норвегії та багатьма іншими партнерськими організаціями, що надає магістрантам унікальну можливість для стажувань. Навчання гнучке, що дає можливість студентам навчатися по обміну 3 університетами-партнерами в Свропі.

Дворічну (120 кредитів ECTS) міжнародну програму магістра зі спортивного менеджменту викладають англійською мовою, вона охоплює 90 кредитів ECTS та магістерську роботу - 30 кредитів ECTS. Поєднання різної тематики, пов'язаної зі спортом, конкретних завдань зі спортивного управління, забезпечує стажування у 15 кредитів ECTS, яке $є$ ефективним у формуванні професійної компетентності майбутніх менеджерів зі спорту.

Кредит охоплює всі види робіт магістранта, зокрема лекції, семінарські, лабораторні та практичні заняття, самостійну роботу, виконання курсових робіт, консультації. Один кредит ECTS становить 30 годин. Семестр магістрант проводить за кордоном в одному з рекомендованих європейських університетівпартнерів.

Щоб вступити на магістерську програму, кандидатові потрібно мати ступінь бакалавра (BBA, BA, BSc), що еквівалентний мінімуму 180 ECTS кредитів у сфері спортивного менеджменту, ділового адміністрування, соціальних наук (економіка, соціологія, політологія чи історія) тощо. Магістерська програма підходить для кандидатів, які працюють або планують працювати у спортивних клубах, спортивних асоціаціях або інших типах організацій (агентства, медіа, організатори заходів тощо).

Мета програми магістра наук зі спортивного менеджменту (Master of Science in Sport Management) полягає в отриманні сучасних знань економічних i організаційних теорій щодо управління спортом, спеціалізованих знань у сфері спортивного менеджменту, грунтовних знань наукових методів і філософії, наук, що належать до сфери спорту.

Програма магістра наук зі спортивного менеджменту призначена для підготовки студентів до роботи на керівних посадах у сфері спорту. Програма має на меті донести до студентів чітке розуміння та знання про спорт, а також ознайомити студентів з юридичними, етичними, економічними, організаційними, історичними, політичними та психологічними науками, які необхідні для 
Журнал«Герспективита інновації наукия

(Серія«Гедагогіка», Серія«Гцихологія», Серія«Медицина»

№4(4) 2021

подальшої управлінської діяльності в спортивній сфері. Зміст і структуру програми подано у табл. 1.

На курсах програми використовують широкий спектр методів та способів навчання: лекції, завдання, дискусії, робота в команді та стажування.

Деякі курси проводять протягом одного семестру зі заняттями один або два рази на тиждень, тоді як інші курси організовують як семінари з інтенсивним тижневим навчанням. Магістранти повинні працювати індивідуально між лекціями. Під час навчання магістранти проходять стажування у спортивній організації. Упродовж двох останніх семестрів проводять дослідження науководослідного проєкту та написання магістерської роботи.

Робоче навантаження програми становить не менше 40 годин на тиждень. Протягом першого року в середньому процес навчання триває від 10 до 15 контактних годин (викладання, семінари та нагляд) на тиждень. На другому курсі магістранти значну частину свого часу використовують на стажуваннях та для дослідження наукової роботи. Програма не підходить для дистанційного навчання.

Пройшовши магістерську програму в Університетському коледжі Молде (Molde University College) на магістерській програмі Магістра наук зі спортивного менеджменту (Master of Science in Sport Management), магістранти набувають такі компетентності, які формують їх як фахівців у сфері спортивного менеджменту:

- уміти вирішуваати ситуації / проблеми в організаціях, аналітично та структуровано обгрунтувати їх;

- уміти працювати самостійно;

- мати навички та досвід у командній роботі;

- уміти вирішувати професійні питання, що стосуються управління спортом, як на експертному, так і на загальному рівні;

- аналітичне мислення та формування власної думки;

- уміння писати наукові тексти теоретично та методологічно обгрунтувавши;

- застосовувати критичне мислення до пошуку якісних наукових джерел;

- креативність щодо подачі інформації, як усної, так і письмової.

Таблиця 1

Зміст і структура програми Магістра наук зі спортивного менеджменту (Master of Science in Sport Management) в Університетському коледжі Молде (Molde University College) Норвегіï

\begin{tabular}{|l|l|c|c|}
\hline Семестр & $\begin{array}{l}\text { Код } \\
\text { модуля }\end{array}$ & Обов'язкові модулі & $\begin{array}{l}\text { Кредит } \\
\text { ЕСTS }\end{array}$ \\
\hline \multirow{5}{*}{ Перший } & ADM715 & $\begin{array}{c}\text { Основи організації та управління } \\
\text { (Ваsics in organization and management) }\end{array}$ & 7,5 \\
\cline { 2 - 4 } & ADM825 & $\begin{array}{c}\text { Спеціальні питання організації та управління } \\
\text { (Special Issues in Organization and Management) }\end{array}$ & 7,5 \\
\cline { 2 - 4 } & IDR705 & Iсторія спорту (Sports History) & 7,5 \\
\cline { 2 - 4 } & IDR806 & $\begin{array}{c}\text { Сучасні питання управління cпортом } \\
\text { (Contemporary Issues in Sport Management) }\end{array}$ & 7,5 \\
\hline
\end{tabular}




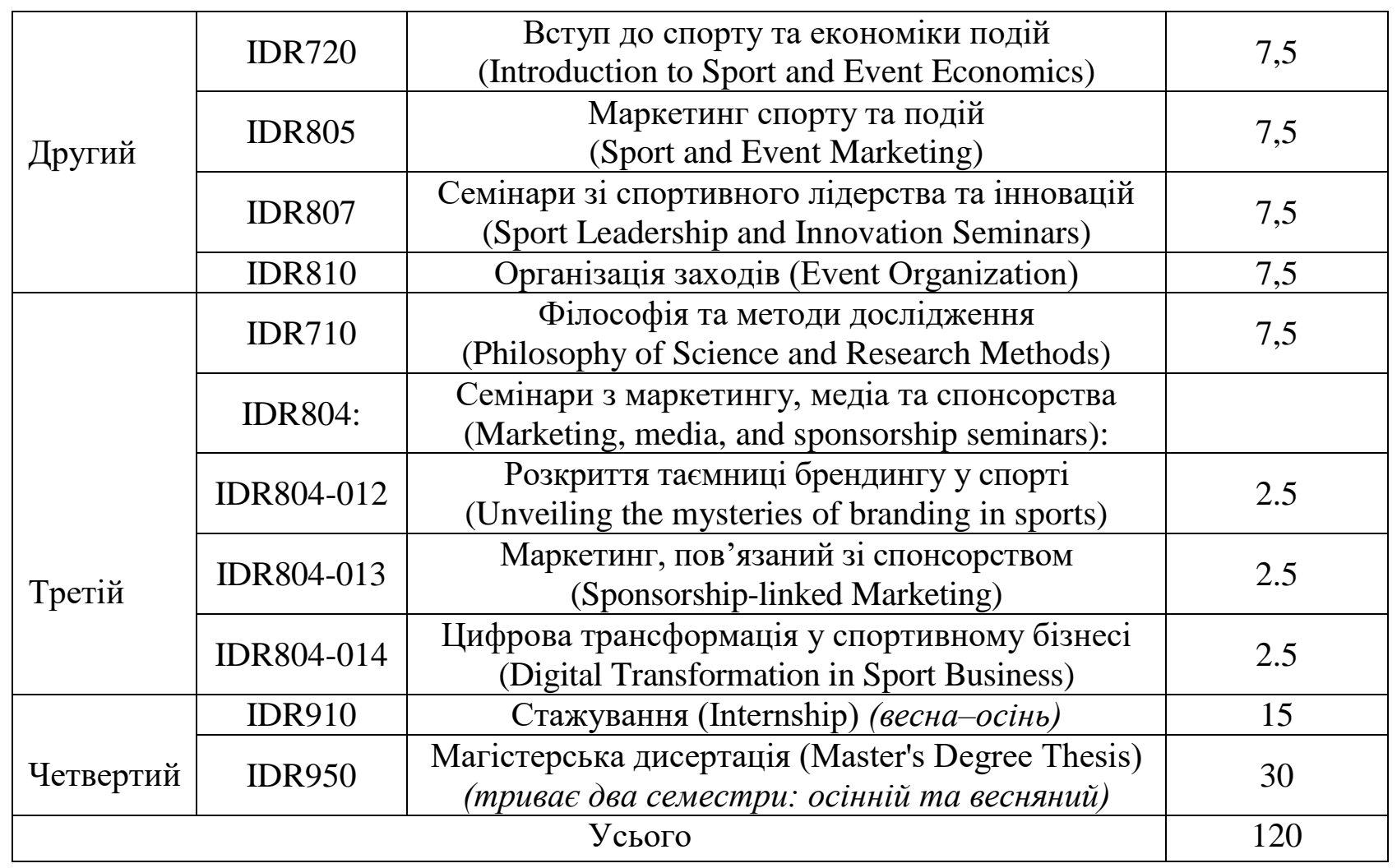

Отже, навчальна програма, спрямована на те, щоб дати магістрантам можливість зрозуміти складність, неоднорідність завдань у сфері фізичної культури і спорту. В Університетському коледжі Молде (Molde University College) пріоритетними $є$ заняття з формування соціальних навичок магістрантів, а саме вміння слухати і бути чуйними до оточуючих, щоб продукувати ефективні рішення та створювати корпоративні середовища, у якому продуктивно відбуватимуться організаційні процеси. Проходячи стажування у спортивних організаціях та завершуючи магістерську роботу, магістранти розвивають свої здібності щодо вирішення проблеми шляхом ії визначення та дослідження, зокрема вивчення, аналізу, усунення та відстоювання своїх ідей.

Університет Мальме (Malmö University) - дев'ятий найбільший вищий навчальний заклад Швеції з 24000 студентами. Місія Університету - бути активним центром досліджень, освіти та інновацій. Студенти мають можливість навчатися за кордоном, оскільки цей навчальний заклад має підписані угоди 3 близько 250 університетами по всьому світу. В Університеті $є$ багато міждисциплінарних програмам, за допомогою яких студенти навчаються на різних факультетах, що мають вирішальне значення для все більш складного ринку праці в умовах сьогодення [4].

Магістр спортивних наук (два роки) (Master i idrottsvetenskap (två år) - це дворічна магістерська програма (Основна галузь: Спортивні науки (Huvudområde: Sportvetenskap)), яка вивчає питання у сфері спорту та спортивної 
Журнал«Герспективитаінновації науки»

(Серія«Гедагогіка», Серія«ГЕихологія», Серія«Медицина»

№4(4) 2021

науки. Програма спрямована на забезпечення місцевих, регіональних, національних та міжнародних запитів у галузі спорту, спортивної науки та сталого суспільства. Освіта тісно пов’язана з науково-дослідним середовищем спортивної науки в Університеті Мальме (Malmö University), який має якісне дослідницьке середовище та визначну роль у наукових суперечностях 3 питань спорту [4].

Для вступу на програму Магістр спортивних наук (два роки) (Master i idrottsvetenskap (två år)) існують певні вимоги, зокрема претендент має мати ступінь бакалавра (180 кредитів або еквівалент іноземного ступеня, мінімум 90 кредитів у галузі спортивної науки, спортивних досліджень, спортивних та фізичних наук, спортивного менеджменту, спортивного бізнесу, вивчення руху людей, кінезіології, фізичної культури, спортивної політики, спортивна психологія, громадське здоров’я, фізичні вправи та харчування, управління відпочинком або еквівалент). Програму викладають англійською мовою [4].

Програма спрямована на те, щоб магістрант розвивав практичні навички та отримував знання, що необхідні для роботи в організаціях, які займаються спортом, відпочинком та охороною здоров'я, як об'єктів для якісних соціальних змін. Основну увагу приділяють здатності магістранта використовувати різні теорії та методи для розуміння, аналізу, змін і використання спорту щодо сталого розвитку та рівноправності суспільства.

Магістерська програма складається зі 120 кредитів і містить як обов'язкові, так і вибіркові курси. Вона охоплює обов'язкові курси підвищення кваліфікації 105 кредитів, з них 90 кредитів обов'язкові за основною сферою та вибіркові курси з 15 кредитів, які відповідають магістерській програмі. Їх можна обирати як в Університеті Мальме (Malmö University), так і в інших коледжах та університетах за консультацією 3 адміністратором програми. Навчання грунтується на лекціях, семінарах та самостійному навчанні, а також навчання може проводитися дистанційно (табл. 2).

Програма є денною i надає можливість отримати ступінь Магістр спортивних наук (Master i idrottsvetenskap) після того, як магістрант виконав вимоги курсу. Для цього він повинен самостійно виконати магістерську роботу, щонайменше 30 кредитів ECTS за основною галуззю знань: Спортивні науки. Самостійна робота може становити менше 30 кредитів ECTS, але не менше 15 кредитів ECTS, якщо магістрант уже здобув незалежну ступінь, яка становить не менше 15 кредитів ECTS в основній сфері навчання або еквівалент із закордонної освіти. 
Таблиия 2

Фрагмент навчальної програми Магістр спортивних наук (два роки) (Master i idrottsvetenskap (två år) у Швецькому університеті Мальме (Malmö University)

\begin{tabular}{|c|c|c|c|c|}
\hline \multicolumn{2}{|l|}{ Семестр } & $\begin{array}{l}\text { Код } \\
\text { модуля }\end{array}$ & Назва модуля & $\begin{array}{l}\text { Кількість } \\
\text { кредитів } \\
\text { (ECTS) }\end{array}$ \\
\hline \multirow{4}{*}{ 党 } & \multirow{6}{*}{ 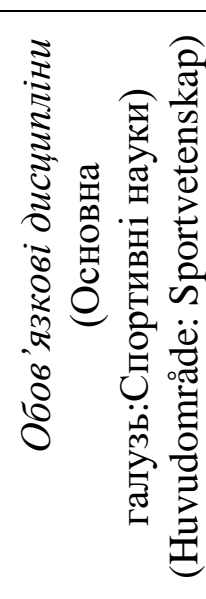 } & IV601G & $\begin{array}{l}\text { Спорт у суспільстві - для вирішення проблем } \\
\text { (Idrott i samhället - Att ta itu med utmaningar) }\end{array}$ & 7,5 \\
\hline & & IV602G & $\begin{array}{l}\text { Глобалізація, спорт та здоров'я } \\
\text { (Globalisering, sport och hälsa) }\end{array}$ & 7,5 \\
\hline & & IV603G & $\begin{array}{l}\text { Перспективи спорту в мінливому світі } \\
\text { (Perspektiv på sport i en föränderlig värld) }\end{array}$ & 7,5 \\
\hline & & IV604G & $\begin{array}{l}\text { Управління спортом - від місцевого до } \\
\text { міжнародного рівня (Sportstyrning - från lokal } \\
\text { till internationell nivå) }\end{array}$ & 7,5 \\
\hline \multirow{2}{*}{$\begin{array}{l}\text { Весна- } \\
\text { Семестр } \\
2\end{array}$} & & IV605G & $\begin{array}{l}\text { Спорт та сталий розвиток } \\
\text { (Sport och hållbar utveckling) }\end{array}$ & 7,5 \\
\hline & & IV606G & $\begin{array}{l}\text { Методи дослідження у сфері спортивних наук } \\
\text { (Forskningsmetoder i idrottsvetenskap) }\end{array}$ & 7,5 \\
\hline \multirow{3}{*}{ 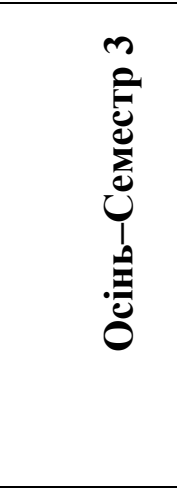 } & \multirow{4}{*}{ 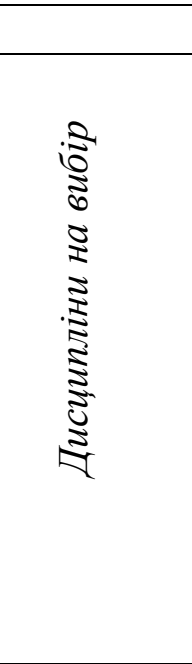 } & & Дисципліни на вибір: & 15 \\
\hline & & & $\begin{array}{l}\text { Дослідження та розробка (R\&D) з акцентом } \\
\text { на спорт у суспільстві } \\
\text { (Forskning och utveckling (FoU) med fokus på } \\
\text { idrott i samhället) } \\
\text { (Основна галузь: Спортивні науки) } \\
\text { (Huvudområde: Sportvetenskap) }\end{array}$ & 15 \\
\hline & & & $\begin{array}{l}\text { Наукова методологія та аналіз } \\
\text { (Vetenskaplig metodik och analys) } \\
\text { (Основна галузь: Спортивні науки) } \\
\text { (Huvudområde: Sportvetenskap) }\end{array}$ & 15 \\
\hline \multirow[t]{2}{*}{$\begin{array}{l}\text { Весна- } \\
\text { Семестр } \\
4\end{array}$} & & & $\begin{array}{l}\text { Спортивні науки: магістерська робота } \\
\text { (Idrottsvetenskap: magisterexamen), } \\
\text { (Основна галузь: Спортивні науки) } \\
\text { (Huvudområde: Sportvetenskap) }\end{array}$ & 30 \\
\hline & \multicolumn{3}{|r|}{ Усього } & 120 \\
\hline
\end{tabular}

Після завершення магістерської програми, Університет Мальме видає сертифікат за заявою, ступінь Магістра спортивних наук (Master i idrottsvetenskap). Шведський сертифікат має також англійський переклад. Магістр спортивних наук (Master i idrottsvetenskap) набуває компетентності, знання та розуміння необхідні для роботи зі спортом стосовно сталого розвитку суспільства. Перспектива щодо отримання робочих місць для майбутніх менеджерів доволі велика - як робота зі спортсменами, так і робота у спортивних федераціях чи секторах охорони здоров'я.

Під час програми магістранти розвивають практичні навички та базу знань для роботи у сфері спорту, дозвілля та охорони здоров'я як платформи соціальних змін. Завершуючи магістерське дослідження, магістранти отримають 
ступінь, престижний європейський диплом, який їм дає можливість займатися як науковою діяльністю, так i роботою на керівних посадах в організаціях спортивного спрямування.

Висновки. Формування професійної компетентності менеджерів у сфері спорту Скандинавських країн відбувається на високому професійному рівні. Для оптимального способу отримання знань використовують та шукають нові інноваційні методи навчання. Також у закладах вищої освіти активно діють програми 3 обміну студентів із провідними вишами Свропи. Магістрантів навчають мислити вільно, критично та креативно. Сама система освіти Скандинавських країн спрямована на формування соціальних навичок магістрантів, а саме вміння слухати i бути чуйними до оточуючих, щоб продукувати ефективні рішення та створювати корпоративне середовища, у якому успішно відбуватимуться управлінські процеси. Проходячи стажування у спортивних організаціях та завершуючи магістерську роботу, магістранти розвивають свої здібності щодо вирішення проблеми шляхом іiі визначення та дослідження, зокрема вивчення, аналізу, усунення та відстоювання своїх ідей. Магістри, які завершили навчання у вишах Скандинавських країн, мають перспективи кар'єрного зростання та можливості отримати роботу в Свропі та США, адже тутешня вища освіта вважається однією з найкращих у світі.

\section{Лimepamypa:}

1. Скрипник В. Навчання у Скандинавії. Курс молодого вікінга [Електронний ресурс] / В. Скрипник. - 2013. Режим доступу: https://osvita.ua/abroad/higher_school/articles/33970/

2. Головчанська $Є$. Руйнуємо міфи про освіту за кордоном. Навчання в Норвегії: стереотипи, реальність і можливості навчання для іноземців у країні фіордів [Електронний ресурс] / Головчанська Є. - 2017. Режим доступу: http://www.univer.tv/tips/perspectiva/ruynu-mo-m-fi-proosv-tu-za-kordonom-navchannya-v-norveg-stereotipi-realn-st-mozhlivost-navchannya-d/

3. Molde University Collegehttps [Site of Molde University Collegehttps]. Available from: https://www.masterstudies.no/universiteter/Norge/Molde-University-College

4. Malmö University [Site of Malmö University]. Available from: https://www.masterstudies.se/ universitet/Sverige/MalmB6-University

\section{References:}

1. Skrypnyk V. (2013) Navchannya u Skandynaviyi. Kurs molodoho vikinha. [Studying in Scandinavia. Young Viking course]. Retrieved from https://osvita.ua/abroad/higher_school/articles/33970/

2. Holovchanska YE. (2017) Ruynuyemo mify pro osvitu za kordonom. Navchannya v Norvehiyi: stereotypy, realnist i mozhlyvosti navchannya dlya inozemtsiv u krayini fiordiv [We destroy the myths about education abroad. Studying in Norway: stereotypes, reality and learning opportunities for foreigners in the country of the fjords]. Retrieved from: http://www.univer.tv/tips/perspectiva/ruynu-mo-m-fi-pro-osv-tu-za-kordonom-navchannya-v-norvegstereotipi-realn-st-mozhlivost-navchannya-d/

3. Molde University Collegehttps [Site of Molde University Collegehttps]. Retrieved from: https://www.masterstudies.no/universiteter/Norge/Molde-University-College

4. Malmö University [Site of Malmö University]. Retrieved from: https://www.masterstudies.se/ universitet/ Sverige/MalmB6-University 